\title{
FAKTOR-FAKTOR BROADEN BUILD YANG MEMPENGARUHI KINERJA KELEMBAGAAN PADA LEMBAGA SEKURITAS DI MALANG
}

\author{
Erna Retna Rahadjeng \\ Fakultas Ekonomi dan Bisnis Universitas Muhammadiyah Malang \\ E-mail:erna_retna@yahoo.co.id
}

\begin{abstract}
This study aims to identify the performing of an agency applying nuturing institutional capital markets through built Broaden approach to improve the performance of securities institution. This phenomenological study was conducted on securities agency in Malang. The data has been collected by using participant observation, indepth interviews, and questionnaires. The data was anlyzed by using content analysis. Based on the result, the researcher concluded that the variables (x1) Emotional Resiliency; (x2) Cognitive Resiliency; (x3) social resiliency; and Financial Resiliency (x4) have jointly significant influence on the performance of securities agency. Similarly, each variable partially has an influence on financial performance. The dominant variable influencing the performance of securities agency is cognitive resiliency variable that has the highest value of regression coefficient. Therefore, the hypothesis stated about there is an influence of emotional resiliency; cognitive resiliency; social resiliency; and financial resiliency variables towards the performance of the securities agency in Malang is accepted.
\end{abstract}

Keywords: Capital Markets, Securities Agency, nuturing, Broaden Build

\begin{abstract}
Abstrak
Penelitian ini bertujuan untuk mengidentifikasi kinerja kelembagaan dengan model nuturing kelembagaan pasar modal melalui pendekatan broaden built untuk meningkatkan kinerja lembaga sekuritas. Penelitian fenomenologi ini dilakukan pada lembaga Sekuritas di Malang. Tehnik pengumpulan data dilakukan dengan observasi partisipatorik, wawancara mendalam, dan kuesioner. Analisis data yang digunakan adalah Content Analysis. Hasil yang diperoleh adalah maka dapat ditarik kesimpulan bahwa Variabel (x1) Emotional Resiliency; (x2) Cognitive Resiliency; (x3) social resiliency; dan Financial Resiliency $(x 4)$ secara bersama-sama mempunyai perngaruh yang signifikan terhadap kinerja Lembaga sekuritas. Begitu pula secara parsial masing-masing variabel memiliki pengaruh terhadap kinerja keuangan. Variabel yang dominan berpengaruh terhadap kinerja lembaga Sekuritas adalah variabel cognitive resiliency yang memiliki nilai koefisien regresi tertinggi. Sehingga hipotesis yang menyatakan adanya pengaruh variabel Emotional Resiliency; Cognitive Resiliency; social resiliency; dan Financial Resiliency terhadap kinerja Lembaga Sekuritas di Malang diterima.
\end{abstract}

Kata Kunci: Pasar Modal, Lembaga Sekuritas, Nuturing, Broaden Build

Pasar modal merupakan pasar berbagai instrumen keuangan jangka panjang yang mem- perjualbelikan, baik dalambentuk utang ataupun modal sendiri yang menjadi salah satu 
sumber untuk mendapatkan dana atau modal untuk pembiayaan pembangunan nasional. Pasar Modal adalah pasar yang memperdagangkan surat-surat berharga sebagai bukti kepemilikan suatu perusahaan bisnis atau kepemilikan modal untuk diinvestasikan sesuai dengan kesepakatan yang telah dibuat. Contohnya seperti saham, reksadana, obligasi perusahaan swasta dan pemerintah, dan lain sebagainya. Adanya pasar modal sebagai salah satu pelaku ekonomi nasional memilikifungsi intermediasi yaitu menjembatani antara pihak yang membutuhkan modal dengan pihak yang kelebihan modal, serta memperbanyak pilihan sumber dana bagi perusahaan swasta dan pemerintah. Jangkauan dan misi pasar modal di Indonesia mencakup tiga aspek mendasar yang ingin dicapai yaitu; mempercepat proses perluasan partisipasimasyarakat, pemerataan pendapatan masyarakat, menggairahkan partisipasi masyarakat dalam pengarahan dan perhimpunan dana untuk digunakan secara produktif.

Investasi pada saham mempunyai keunggulan, yaitu akan memperoleh return yang berasal dari capital gain dan dividen. Dividen yang diperoleh oleh seorang investor ditentukan oleh kemampuan perusahaan dalam memperoleh laba. Return yang berasal dari capital gain yang diperoleh, juga dipengaruhi oleh fluktuasi harga saham. Kemampuan perusahaan memperoleh laba dipengaruhi oleh faktor mikro dan makro yang pada gilirannya akan berpengaruh terhadap fluktuasi harga saham. Kedua faktor tersebut akan mempengaruhi risiko investasi saham. Masyarakat Indonesia seringkali mudah terbuai dengan berbagai janji tingkat pengembalian yang tinggitanpa mempelajaribagaimana perusahaan atau investasi tersebut beroperasi. Satu hal yang juga dilupakan oleh mereka para investor adalah sisi mata uang lainnya da- lam berinvestasi, yaitu risiko. Hampir dipastikan bahwa tidak ada investasi yang memberikan keuntungan sangat fantastis tapi tidak memiliki risiko sama sekali. Oleh karenanya, perilaku keuangan individu dalamberinvestasi sangatlah penting.

Lembaga sekuritas yang ada di Malang pada umumnya sudah melakukan pembenahan baik secara fisik maupun non fisik, selama inilembaga Sekuritas diMalang dalammelaksanakan kegiatannya baik cara mendapatkan investor dan calon investor maupun pelaksanaan trading dilembaga sekuritas, hanya berdasarkan kebutuhan pasar dalam arti untuk mendapat investor dan calon investor yang ada di Malang dengan pendekatan individual dan memberikan informasi tentang kelebihannya saja tanpa menjelaskan dampak negatifnya selain itu lembaga sekuritas yang ada di Malang belum memberikan edukasi bagi calon investor sehingga banyak yang tidak mengetahui tentang mekanisme perdagangan di pasar modal, selain itu lembaga sekuritas di Malang banyak yang belum melakukan sosialisasi keberadaan mereka kepada masyarakat Malang pada umumnya.

Dalamera persaingan yang semakin ketat, setiap kalisebuah perusahaan harus mengevaluasi kinerjanya, serta melakukan serangkaian perbaikan, agar tetap tumbuh dan dapat bersaing. Perbaikan ini akan dilaksanakan secara terus menerus, sehingga kinerja perusahaan makin baik dan dapat terus unggul dalam persaingan, atau minimal tetap dapat bertahan.

Berdasarkan fenomena yang ada, masih banyak lembaga sekurita yang kurang akurat dalammemberikan informasi kepadainvestor, khususnya parainvestor baru. Pada umumnya investor baru yang hendak melakukan investasi, masih bergantung kepada pola investasi investor lama. Hal tersebut tentunya 
dapat mempengaruhi nilai keuntungan yang akan diperoleh, semisal keuntungan yang diperoleh para investor baru tersebut kurang maksimal karena ketidaktahuan mereka terhadap bagaimana perusahaan dan investasi tersebut beroperasi bahkan keberadaan sekuritas banyak yang tidak mengetahui keberadaan kantornya.

Sebagai solusi dari berbagai permasalahan yang dihadapikelembagaan pasar modal dalam pengambilan keputusan untuk menarik investor adalah melalui penerapan model nuturing kelembagaan melalui pendekatan broaden build untuk meningkatkan kinerja lembaga sekuritas. Peneliti membatasi penelitian ini pada lokasi penelitian yaitu hanya pada lembaga sekuritas yang berada di kota Malang, dan metode analisisnya hanya terbatas pada analisis sederhana yaitu dengan metode tabulasi data untuk menjawab rumusan masalah. Berdasarkan latar belakang di atas, maka peneliti dapat menarik rumusan masalah sebagai berikut: (1) faktor-faktor apa saja yang mempengaruhi lembaga sekuritas dalam mendapatkan investor di Malang? (2) Bagaimana model nuturing kelembagaan melalui pendekatan broaden build mempengaruhi lembaga sekuritas dalam pengambilan keputusan menarik investor di Malang? (3) Model nuturing broaden build yang bagaimana dapat meningkatkan kinerja lembaga sekuritas di Malang?

Lembaga Sekuritas sebagai lembaga mediator antara pemilik dana (investor) dengan emiten yang selalu dituntut untuk meningkatkan kinerjanya agar para investor dapat memiliki energi dan antusiasme yang kemudian membentuk penilaian positif atas niat dan keputusan untuk berinvestasi dengan nyaman dan tenang. Dalam upaya meningkatkan kinerjanya lembaga sekuritas perlu melakukan perbaikan secara terus-menerus melalui pen- dekatan broaden build. Adapun tujuan dari penelitian ini adalah untuk mengetahui faktor-faktor yang mempengaruhi lembaga sekuritas dengan menerapkan model nuturing kelembagaan melalui pendekatan broaden build guna meningkatkan kinerja lembaga sekuritas di Malang. Penerapan model nuturing melalui pendekatan broaden build ini diharapkan lembaga sekuritas dapat memiliki kinerja positif sehingga mampu menemukan solusi dari berbagai persoalan yang dihadapi dalam pengambilan keputusan menarik investor.

\section{Metode Penelitian}

Jenis penelitian yang digunakan dalampenelitian ini adalah penelitian fenomenologiyang ingin menjelaskan fenomena yang berupa pengalaman-pengalaman yang dialami pengelola, pialang (broker), dan investor dalam pengambilan keputusan berinvestasi di pasar modal khususnya di lembaga sekuritas yang berada di kota Malang. Objek penelitian dalam penelitian ini adalah lembaga sekuritas yang berada di Kota Malang, yaitu lembaga yang selama inimerupakan lembaga perdagangan efek di mana tempat bertemunya para investor, pialang/broker maupun pengelola lembaga sekuritas. Metode pengumpulan data yang digunakan dalampenelitian ini adalah: (1) Observasi peran serta (Participatoric Observation) untuk mengamati investor dalam proses pengambilan keputusan berinvestasi dengan pendekatan Broaden Build. (2) Wawancara mendalam(Indepth Interview). (3) Kuesioner untuk mendapatkan informasi yang akurat tentang lembaga sekuritas

Analisis data yang digunakan dalam penelitian ini adalah analisis kualitatif dengan cara analisis isi (Content Analysis). Analisis isi adalah suatu teknik yang sistematik untuk menganalisis makna pesan dan cara 
mengungkapkan pesan. Langkah yang dilakukan pada analisis isi dalam penelitian ini menggunakan interactive model dari Miles dan Huberman (Miles \& Huberman, 1994). Model inimengandung 4 komponen yang saling berkaitan, yaitu (a) pengumpulan data (b) penyederhanaan atau reduksi data (3) penyajian data (4) penarikan dan pengujian atau verifikasi simpulan. Hasil dari analisis selanjutnya akan disajikan bentuk tabulasi silang dan narasi darifenomena seperti pada gambar 1.

\section{Hasil Penelitian dan Pembahasan}

Berdasarkan data yang diperoleh selama penyebaran quesioner diperoleh karakteristik masing-masing responden antara lain: Berdasarkan hasil perhitungan jumlah sampel pada penelitian ini ditetapkan sebesar 15 lembaga Sekuritas dengan responden Pemilik atau pengelola lembaga sekuritas, broker/ pialang dan investor. Masing-masing responden diwakili 15-20 orang jadi berdasarkan kuesioner yang dikembalikan sebanyak 55 . Setelah dilakukan pemeriksaan kelengkapan data pada kuesioner, yang memenuhi syarat untuk diuji sebesar 50 kuesioner.

Deskripsi responden dalam penelitian ini diklasifikasikan berdasarkan umur, jenis ke- lamin, pendidikan, status usaha, umur perusahaan, jumlah tenaga kerja, asset, omzet penjualan, keuntungan, jenis dan motif batik, jangkauan pemasaran dan distribusi penjualan. Deskripsi responden berdasarkan umur dapat ditunjukkan pada Tabel 1 .

Tabel 1. Deskripsi Responden Berdasarkan Umur

\begin{tabular}{cccc}
\hline No & $\begin{array}{c}\text { Umur } \\
\text { Responden } \\
(\text { Th })\end{array}$ & $\begin{array}{c}\text { Jumlah } \\
\text { (orang) }\end{array}$ & $\%$ \\
\hline 1 & $>30-40$ & 20 & 40 \\
2 & $>40-50$ & 17 & 34 \\
3 & $>50-60$ & 13 & 26 \\
& Total & 50 & 100 \\
\hline
\end{tabular}

Sumber: Data penelitian diolah (2013)

Pada tabel 1 dapat diketahui bahwa respoden terbanyak berada pada kisaran umur 30 - 40 tahun yaitu sebanyak 20 orang atau $40 \%$ dan 17 orang atau $34 \%$ berada pada kisaran umur 41 - 50 tahun, serta urutan ketiga berada pada kisaran $51-60$ tahun sebanyak 13 orang atau sebesar $26 \%$ Pada umumnya mereka adalah merupakan generasi yang memiliki komitmen tinggidipasar modal. Deskripsi responden ditinjau dari jenis kelamin dapat dilihat pada Tabel 2 .

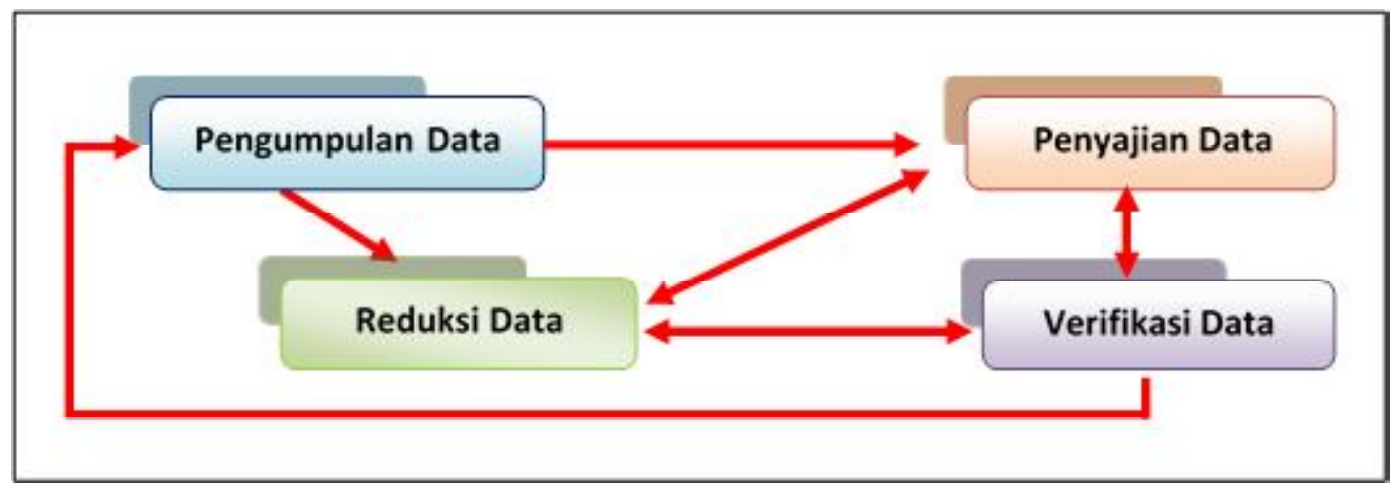

Gambar 1. Komponen-komponen Analisis Data: Model Interaktif 
Faktor-faktor Broaden Bulid yang Mempengaruhi Kinerja.... (Erna Retna Rahadjeng)

Tabel 2. Deskripsi Responden Berdasarkan Jenis Kelamin

\begin{tabular}{cccc}
\hline No & $\begin{array}{c}\text { Jenis } \\
\text { Kelamin }\end{array}$ & $\begin{array}{c}\text { Jumlah } \\
\text { (orang) }\end{array}$ & $\%$ \\
\hline 1 & Laki-laki & 30 & 60 \\
2 & Perempuan & 20 & 40 \\
& Total & 50 & 100 \\
\hline
\end{tabular}

Sumber: Data penelitian diolah (2013)

Berdasarkan Tabel 2 dapat diketahui bahwa responden laki-laki sebesar 30 orang atau $60 \%$, dan sisanya responden perempuan sebanyak 20 orang atau $40 \%$. Ini berarti bahwa para pelaku pasar modal lebih banyak para laki-laki daripada perempuan. Kondisi semacam ini disebabkan oleh karena laki-laki lebih teliti dalam membaca peluang dan memiliki jiwa berani mengambil risiko daripada perempuan. Ditinjau dari pendidikan responden dalam penelitian dapat digambarkan pada Tabel3.

Tabel 3. Deskripsi Responden Berdasarkan Pendidikan

\begin{tabular}{|c|c|c|c|}
\hline No & Pendidikan & $\begin{array}{l}\text { Jumlah } \\
\text { (orang) }\end{array}$ & $\%$ \\
\hline 1 & $\mathrm{SD} / \mathrm{MI}$ & 4 & 8 \\
\hline 2 & SMP & 7 & 14 \\
\hline 3 & $\begin{array}{l}\text { SMA/ } \\
\text { MAN }\end{array}$ & 19 & 38 \\
\hline 4 & $\begin{array}{c}\text { Sarjana } \\
\text { Total }\end{array}$ & $\begin{array}{l}20 \\
50\end{array}$ & $\begin{array}{c}40 \\
100\end{array}$ \\
\hline
\end{tabular}

Sumber: Data penelitian diolah (2013)
Berdasarkan Tabel 3 dapat diketahui bahwa sebagian besar respoden berpendidikan setingkat SD/MI yaitu sebanyak 4 orang atau $8 \%$, SMP 14\%, SMA 38\% dan selebihnya $40 \%$ atau 20 orang yang berpendidikan sarjana. Ini berarti bahwa mayoritas pelaku pasar modal memiliki pendidikan yang tinggi. Hal ini menunjukkan bahwa di dalam menganalisis pasar diperlukan pengetahuan yang luas dan berpendidikan. Berdasarkan posisi mereka yang saat ini sebagai pemilik/pengelola pasar modal yang sekaligus juga manajer, menjelaskan bahwa faktor pendidikan menjadi dasar yang sangat menentukan. Hasil wawancara yang kamilakukan, mereka menyatakan bahwa pendidikan yang dicapai saat ini sudah lebih baik dibandingkan dengan orang tua sebagai generasi sebelumnya yang kebanyakan tidak berpendidikan formal dalammelakukan transaksi di pasar modal. Ditinjau dari keuntungan responden dapat dideskripsikan pada Tabel 4.

Dari tabel 4 dapat diidentifikasi bahwa mayoritas responden dalam penelitian ini sebanyak 15 orang atau $30 \%$ memiliki keuntungan $\leq$ Rp 100.000.000 pertahun. Responden yang memiliki keuntungan $\mathrm{Rp}$ 101.000.000 - Rp 200.000.000 adalah sebanyak 10 orang atau 20\%. Responden yang memiliki keuntungan $\mathrm{Rp} 201.000 .000$ - Rp 300.000 .000 berjumlah 8 orang atau $16 \%$. Responden yang memiliki keuntungan

Tabel 4. Deskripsi Responden Berdasarkan Keuntungan

\begin{tabular}{ccc}
\hline Keuntungan (Juta/Thn) & Jumlah (orang) & Persentase \\
\hline$\leq \operatorname{Rp~100~}$ & 15 & $30 \%$ \\
Rp 101 - Rp 200 & 10 & $20 \%$ \\
$\operatorname{Rp~201~-~Rp~300~}$ & 8 & $16 \%$ \\
$\operatorname{Rp~301~-~Rp~400~}$ & 5 & $10 \%$ \\
Rp 401 - Rp 500 & 5 & $10 \%$ \\
$\geq \operatorname{Rp~500~}$ & 7 & $14 \%$ \\
Total & 50 & $100 \%$
\end{tabular}

Sumber: Data Primer diolah (2013) 
Rp 301.000.000 - Rp Rp 400.000.000 sebanyak 5 orang atau $10 \%$. Responden yang memiliki keuntungan Rp 401.000.000 - Rp 500.000 .000 sebanyak 5 orang atau $10 \%$. Responden yang memiliki keuntungan $\geq \mathrm{Rp}$ 500.000 .000 sebanyak 7 orang. Dengan demikian keuntungan pertahun masih banyak yang kurang dari Rp 100.000.000 untuk responden di Malang.

Variabel dalam penelitian ini diukur dengan instrumen kuesioner dengan pertanyaan tertutup menggunakan lima pilihan jawaban yaitu Sangat Tidak Setuju (STS, skor 1), Tidak Setuju (TS, skor 2), Netral (N, skor 3), Setuju (S, skor 4), dan Sangat Setuju (SS, skor 5). Deskripsi tiap variabel dalam penelitian ini disajikan dalam bentuk frekuensi dan persentase jawaban responden beserta kriteria interpretasi rata-rata skor dalam lima tingkatan yaitu 1) sangat rendah (rata-rata 1.00-1.80), 2) rendah (rata-rata 1.81-2.60), 3) sedang (rata-rata 2.61-3.40), 4) tinggi (rata-rata 3.414.20), dan sangat tinggi (rata-rata 4.21-5.00).

Variabel Emotional Resiliency (X1) terdiridari6indikator yaitu Temperamen (x1.1), Intelegency (x1.2), Kultur (x1.3), Dorongan agar menjadi otonom (x1.4), Gender (x1.5) dan Age (x1.6). Berdasarkan hasil penelitian, pada Variabel Emotional Resiliency, Indikator pertama Temperamen (x1.1), terlihat bahwa sebanyak 22 orang atau 40,9\% dari responden menjawab sangat setuju, 22 orang atau 33,3\% dari responden masingmasing menjawab setuju dan netral sebanyak 16 orang atau $24,2 \%$ dari responden, sedangkan yang menjawab tidak setuju sebanyak 1 orang atau 1,5\% dan tidak ada satupun responden yang menjawab sangat tidak setuju. Dari nilai rata-rata skor terlihat bahwa nilai 4,14 terletak pada kriteria tinggi (rata-rata antara 3.41 hingga 4.20). Dengan demikian dapat disimpulkan bahwa indika- tor pertama dinilai tinggi oleh responden. Artinya bahwa responden mayoritas menyatakan bahwa pelaku pasar modal mayoritas memiliki temperamen yang tinggi, Hal ini terlihat hampir 50\% yang menjawab dan menyatakan sangat setuju pada pertanyaan yang diajukan tentang temperamen yang dimiliki pelaku pasar modal.

Indikator keduapada Intelegency(x1.2), terlihat bahwa sebanyak 29 orang atau $43,9 \%$ dari responden menjawab setuju, 20 orang atau $30,3 \%$ dari responden menjawab sangat setuju, 13 orang atau $19,7 \%$ dari responden menjawab netral, 4 orang atau $6,1 \%$ menjawab tidak setuju dan tidak ada satupun responden yang menjawab sangat tidak setuju. Dari nilai rata-rata skor terlihat bahwa nilai 3.98 terletak pada kriteria tinggi (rata-rata antara 3.41 hingga 4.20). Dengan demikian dapat disimpulkan bahwa indikator kedua dinilai tinggi oleh responden. Artinya dari hasil jawaban responden menunjukkan bahwa para pelaku pasar modal harus memiliki intelegency yang tinggi di dalam membaca informasi yang ada di pasar modal. Hal ini ditunjukkan darijawaban responden yang menjawab setuju untuk pertanyaan variabel ke dua yaitu tentang kebenaran responden dalam membaca informasi dan menganalisis informasi.

Indikator ketiga Kultur(x1.3), terlihat bahwa sebanyak 30 orang atau $45.5 \%$ dari responden menjawab sangat setuju, 17 orang atau $25,8 \%$ dari responden masing-masing menjawab netral dan responden yang menjawab setuju sebanyak 14 orang atau $21,2 \%$, sedangkan 5 orang atau $7,61 \%$ menjawab tidak setuju dan tidak ada satupun responden yang menjawab sangat tidak setuju. Dari nilai rata-rata skor terlihat bahwa nilai 4.05 terletak pada kriteria tinggi (rata-rata antara 3.41 hingga 4.20). Dengan demikian dapat disimpul- 
kan bahwa indikator ketiga dinilai tinggioleh responden. Artinya bahwa kultur atau budaya dalam investasi di pasar modal di Malang cukup tinggi. Hal ini ditunjukkan dari jawaban responden yang menjawab sangat setuju untuk pertanyaan yang ketiga yaitu tentang kultur atau budaya di dalam berinvestasi di pasar modal.

Indikator keempat adalah dorongan agar menjadi otonom (x1.4), terlihat bahwa sebanyak 35 orang atau $53 \%$ dari responden masing-masing menjawab setuju dan responden yang menjawab netral 22 orang atau $33,3 \%$, sedangkan 5 orang atau $7,6 \%$ dari responden menjawab sangat setuju, 4 orang atau $6,1 \%$ menjawab tidak setuju dan tidak ada satupun responden yang menjawab sangat tidak setuju. Dari nilai rata-rata skor terlihat bahwa nilai 3.62 terletak pada kriteria tinggi (rata-rata antara 3.41 hingga 4.20). Dengan demikian dapat disimpulkan bahwa indikator keempat dinilaitinggioleh responden. Artinya bahwa selama ini responden mengharapkan adanya otonomi tentang kebijakan investasi di pasar modal. Hal ini ditunjukkan dari jawaban responden tentang pertanyaan untuk variabel yang ke empat.

Indikator kelima Gender (x1.5), terlihat bahwa sebanyak 28 orang atau $42,4 \%$ dari responden menjawab netral, 27 orang atau $40,9 \%$ dari responden menjawab setuju, 9 orang atau $13,6 \%$ dari responden menjawab sangat setuju, sedangkan 2 orang atau $3 \%$ menjawab tidak setuju dan tidak ada satupun responden yang menjawab sangat tidak setuju. Dari nilai rata-rata skor terlihat bahwa nilai 3.65 terletak pada kriteria tinggi (rata-rata antara 3.41 hingga 4.20). Dengan demikian dapat disimpulkan bahwa indikator kedua dinilai tinggi oleh responden. Artinya dari hasil jawaban responden menunjukkan bahwa para pelaku pasar modal ber- dasarkan gender artinya di dalam berinvestasi di pasar modal tidak memandang satu jenis kelamin tetapi pria atau wanita memiliki peluang sama dalam berinvestasi di pasar modal, jawaban dari pertanyaan tersebut memilikinilaiyang tinggi. Hal ini ditunjukkan dari jawaban responden yang menjawab setuju untuk pertanyaan variabel ke lima yaitu tentang keberadaan pelaku pasar berdasarkan gender dalam membaca informasi dan menganalisis informasi adalah sama.

Indikator ke enam Age (x1.6), terlihat bahwa sebanyak 31 orang atau $47 \%$ dari responden menjawab netral, sedangkan 22 orang atau 33,3\% dari responden masingmasing menjawab setuju dan responden yang menjawab sangat setuju sebanyak 8 orang atau $12,1 \%$, sedangkan responden sebanyak 5 orang atau $7,6 \%$ menjawab tidak setuju dan tidak ada satupun responden yang menjawab sangat tidak setuju. Dari nilai rata-rata skor terlihat bahwa nilai 3.50 terletak pada kriteria tinggi (rata-rata antara 3.41 hingga 4.20). Dengan demikian dapat disimpulkan bahwa indikator ketiga dinilai tinggioleh responden. Artinya bahwa age (usia) dalam investasi di pasar modal di Malang tinggi. Hal ini ditunjukkan darijawaban responden yang menjawab netral untuk pertanyaan yang ke enam yaitu tentang age (usia) bagi investor yang berinvestasi di pasar modal tidak menjadi halangan.

Dari nilai rata-rata keseluruhan Variabel Aktivitas operasi terlihat bahwa nilai 3.82 terletak pada kriteria tinggi (rata-rata antara 3.41 hingga 4,20). Dengan demikian dapat disimpulkan responden menilai tinggi mengenai variabel Emotional Resiliency.

Berdasarkan hasil analisis Variabel Communication (kemampuan melakukan komunikasi dengan baik) (X2.1) terlihat bahwa sebanyak 24 orang atau 36,4\% dari 
responden menjawab setuju, 21 orang atau $31,8 \%$ dari responden menjawab netral, 15 orang atau $22,7 \%$ dari responden menjawab sangat setuju, 6 orang $(9,1 \%)$ menjawab tidak setuju dan tidak ada satupun responden yang menjawab sangat tidak setuju. Dari nilai rata-rata skor terlihat bahwa nilai 3.73 terletak pada kriteria tinggi (rata-rata antara 3.41 hingga 4.20). Dengan demikian dapat disimpulkan bahwa indikator pertama dinilai tinggi oleh responden.

Indikator kedua Problem Solving (kemampuan menganalisis masalah adalah kemampuan mengidentifikasi secara akurat penyebab dari suatu masalah) (X2.2), terlihat bahwa sebanyak 23 orang atau 34,8\% dari responden menjawab netral, 20 orang atau $30,3 \%$ dari responden menjawab setuju, 14 orang atau $21,2 \%$ dariresponden menjawab sangat setuju, 9 orang atau 13,6\% menjawab tidak setuju dan tidak ada satupun responden yang menjawab sangat tidak setuju. Dari nilai rata-rata skor terlihat bahwa nilai 3.59 terletak pada kriteria tinggi (rata-rata antara 3.41 hingga 4.20). Dengan demikian dapat disimpulkan bahwa indikator kedua dinilai tinggi oleh responden.

Dari nilai rata-rata keseluruhan Variabel Cognitive Resiliency (X2) terlihat bahwa nilai 3,66 terletak pada kriteria tinggi (rata-rata antara 3.41 hingga 4,20). Dengan demikian dapat disimpulkan responden menilai tinggi mengenai variabel Cognitive Resiliency (X2).

Berdasarkan hasil analisis Variabel $\mathrm{So}$ cial Resiliency (X3), Indikator pertama $\mathrm{Ha}$ rapan, keyakinan, dan kepercayaan (x3.1), terlihat bahwa sebanyak 30 orang atau 45,5\% dari responden menjawab setuju, 16 orang atau 24,2\% dari responden masing-masing menjawab sangat setuju dan netral, sedangkan 4 orang atau $6,1 \%$ dari responden men- jawab tidak setuju dan tidak ada satupun responden yang menjawab sangat tidak setuju. Dari nilai rata-rata skor terlihat bahwa nilai 3.88 terletak pada kriteria tinggi (rata-rata antara 3.41 hingga 4.20). Dengan demikian dapat disimpulkan bahwa indikator pertama dinilai tinggi oleh responden. Artinya bahwa responden mayoritas menyatakan bahwa pelaku pasar modal mayoritas memiliki Harapan, keyakinan, dan kepercayaan yang tinggi, Hal ini terlihat hampir 50\% yang menjawab dan menyatakan setuju pada pertanyaan yang diajukan tentang Harapan, keyakinan, dan kepercayaan yang dimiliki setiap individu pelaku pasar modal.

Indikator kedua pada Struktur dan aturan (x3.2), terlihat bahwa sebanyak 27 orang atau 40,9\% dari responden menjawab setuju, 19 orang atau $28,8 \%$ dari responden menjawab sangat setuju, 18 orang atau $27,3 \%$ dari responden menjawab netral, 2 orang atau $3 \%$ menjawab tidak setuju dan tidak ada satupun responden yang menjawab sangat tidak setuju. Dari nilai rata-rata skor terlihat bahwa nilai 3.95 terletak pada kriteria tinggi (rata-rata antara 3.41 hingga 4.20). Dengan demikian dapat disimpulkan bahwa indikator kedua dinilai tinggi oleh responden. Artinya dari hasil jawaban responden menunjukkan bahwa para pelaku pasar modal harus memilikiStruktur dan aturan yang tinggi di dalam berinvestasi di pasar modal agar dalam pengambilan keputusan nantinya tidak mengalami kesalahan atau kerugian. Hal ini ditunjukkan dari jawaban responden yang menjawab setuju untuk pertanyaan variabel ke dua yaitu tentang kebenaran responden dalam membaca dan menganalisis informasi yang ada.

Indikator ketiga Roles model (x3.3), terlihat bahwa sebanyak 22 orang atau $33,3 \%$ dari responden menjawab sangat se- 
tuju, 20 orang atau 30,3\% dari responden masing-masing menjawab setuju dan netral, 4 orang atau $6,1 \%$ menjawab tidak setuju dan tidak ada satupun responden yang menjawab sangat tidak setuju. Dari nilai rata-rata skor terlihat bahwa nilai 3.91 terletak pada kriteria tinggi (rata-rata antara 3.41 hingga 4.20). Dengan demikian dapat disimpulkan bahwa indikator ketiga dinilai tinggi oleh responden. Artinya bahwa Roles model dalam investasi di pasar modal di Malang cukup tinggi. Hal ini ditunjukkan dari jawaban responden yang menjawab sangat setuju untuk pertanyaan yang ke tiga yaitu tentang Roles model di dalam berinvestasi di pasar modal.

Dari nilai rata-rata keseluruhan VariabelAktivitas investasiterlihat bahwa nilai 3,92 terletak pada kriteria tinggi (rata-rata antara 3.41 hingga 4,20). Dengan demikian dapat disimpulkan responden menilai tinggi mengenai variabel Social Resiliency.

Berdasarkan hasil analisis, pada Variabel Financial Resiliency (X4), Indikator pertama Trusting relationships (mempercayai hubungan) (X4.1), terlihat bahwa sebanyak 23 orang atau 34,8\% dari responden menjawab netral, 20 orang atau 30,3\% dari responden menjawab setuju, 14 orang atau $21,2 \%$ dari responden menjawab sangat setuju, 9 orang atau $13,6 \%$ menjawab tidak setuju dan tidak ada satupun responden yang menjawab sangat tidak setuju. Dari nilai rata-rata skor terlihat bahwa nilai 3.59 terletak pada kriteria tinggi (rata-rata antara 3.41 hingga 4.20). Dengan demikian dapat disimpulkan bahwa indikator kedua dinilai tinggi oleh responden.

Indikator kedua pada Variabel Financial Resiliency (X4) yaitu Akses pada kesejahteraan, dan layanan keamanan (X4.2), terlihat bahwa sebanyak 22 orang atau $33,3 \%$ dari responden menjawab ne- tral, 21 orang atau $31,8 \%$ dariresponden menjawab sangat setuju, 15 orang atau $22,7 \%$ menjawab setuju, 8 orang atau $12,1 \%$ menjawab tidak setuju dan tidak ada satupun responden yang menjawab sangat tidak setuju. Dari nilai rata-rata skor terlihat bahwa nilai 3.74 terletak pada kriteria tinggi (rata-rata antara 3.41 hingga 4.20). Dengan demikian dapat disimpulkan bahwa indikator ketiga dinilai tinggioleh responden.

Indikator ketiga pada Variabel Financial Resiliency (X4) yaitu empati, dan altruistik (empati merupakan kemampuan individu untuk bisa membaca bagaimana perasaan dan emosi orang lain) (X4.3), terlihat bahwa sebanyak 36 orang atau 54,5\% dari responden menjawab setuju, 22 orang atau 33,3\% dari responden menjawab netral, 6 orang atau $9,1 \%$ menjawab sangat setuju, 2 orang atau $3 \%$ menjawab tidak setuju dan tidak ada satupun responden yang menjawab sangat tidak setuju. Dari nilai ratarata skor terlihat bahwa nilai 3.70 terletak pada kriteria tinggi(rata-rata antara 3.41 hingga 4.20). Dengan demikian dapat disimpulkan bahwa indikator keempat dinilai tinggi oleh responden.

Dari nilai rata-rata keseluruhan Variabel Financial Resiliency (X4) terlihat bahwa nilai 3,68 terletak pada kriteriatinggi (rata-rata antara 3.41 hingga 4,20). Dengan demikian dapat disimpulkan responden menilai tinggi mengenai variabel Financial Resiliency.

Berdasarkan hasil analisis Variabel kinerja Lembaga Sekuritas di Malang, Indikator pertama yaitu aktivitas/proses(Y1) terlihat bahwa sebanyak 23 orang atau $34,8 \%$ dari responden menjawab setuju, 20 orang atau $30,3 \%$ dari responden menjawab sangat setuju, 18 orang atau 27,3\% dari responden menjawab netral, 5 orang $(7,6 \%)$ 
menjawab tidak setuju dan tidak ada satupun responden yang menjawab sangat tidak setuju. Dari nilai rata-rata skor terlihat bahwa nilai 3,88 terletak pada kriteriatinggi (rata-rata antara 3.41 hingga 4.20). Dengan demikian dapat disimpulkan bahwa indikator pertama dinilai tinggi oleh responden.

Indikator kedua pada Variabel kinerja Lembaga Sekurtas yaitu Output merupakan ukuran-ukuran mengenai jumlah pelayanan yang diberikan atau jumlah layanan yang memenuhi persyaratan kualitas tertentu (Y2), terlihat bahwa sebanyak 24 orang atau $36,4 \%$ dari responden menjawab setuju, 19 orang atau $28,8 \%$ dari responden menjawab sangat setuju, 16 orang atau $24,2 \%$ dari responden menjawab netral, 7 orang atau $10,6 \%$ menjawab tidak setuju dan tidak ada satupun responden yang menjawab sangat tidak setuju. Darinilai rata-rata skor terlihat bahwa nilai 3.83 terletak pada kriteria tinggi (rata-rata antara 3.41 hingga 4.20). Dengan demikian dapat disimpulkan bahwa indikator kedua dinilai tinggi oleh responden.

Indikator ketiga pada Variabel Kinerja Lembaga Sekuritas yaitu Outcome merupakan ukuran tentang hasil yang timbul karena adanya layanan yang diberikan. (Y3), terlihat bahwa sebanyak 29 orang atau 43,9\% dari responden menjawab sangat setuju, 19 orang atau $28,8 \%$ dari responden menjawab sangat setuju, 12 orang atau $18,2 \%$ menjawab netral, 6 orang atau 9,1\% menjawab tidak setuju dan tidak ada satupun responden yang menjawab sangat tidak setuju. Dari nilai rata-rata skor terlihat bahwa nilai 3,92 terletak pada kriteria tinggi (rata-rata antara 3.41 hingga 4.20). Dengan demikian dapat disimpulkan bahwa indikator ketiga dinilai tinggi oleh responden.

Indikator keempat pada Variabel Kinerja Lembaga Sekuritas yaitu Selama3 (tiga) tahun terakhir biaya/efisiensi (Y4), terlihat bahwa sebanyak 23 orang atau 34,8\% dari responden menjawab setuju, 20 orang atau $30,3 \%$ dari responden menjawab sangat setuju, 18 orang atau $27,3 \%$ menjawab netral, 5 orang atau $7,6 \%$ menjawab tidak setuju dan tidak ada satupun responden yang menjawab sangat tidak setuju. Dari nilai rata-rata skor terlihat bahwa nilai 3.88 terletak pada kriteria tinggi (rata-rata antara 3.41 hingga 4.20). Dengan demikian dapat disimpulkan bahwa indikator keempat dinilai tinggi oleh responden.

Indikator kelima pada Variabel Kinerja Lembaga Sekuritas yaitu kualitas/kepuasan pelanggan (Y5), terlihat bahwa sebanyak 24 orang atau 36,4\% dari responden menjawab setuju, 19 orang atau $28,8 \%$ dari responden menjawab sangat setuju, 16 orang atau $24,2 \%$ menjawab sangat netral, 7 orang atau $10,6 \%$ menjawab tidak setuju dan tidak ada satupun responden yang menjawab sangat tidak setuju. Dari nilai rata-rata skor terlihat bahwa nilai 3.83 terletak pada kriteria tinggi (rata-rata antara 3.41 hingga 4.20). Dengan demikian dapat disimpulkan bahwa indikator kelima dinilai tinggi oleh responden.

Indikator keenam pada Variabel Kinerja Lembaga Sekuritas yaitu benchmarks (Y6), terlihat bahwa sebanyak 29 orang atau 43,9\% dari responden menjawab setuju, 19 orang atau $28,8 \%$ dari responden menjawab sangat setuju, 12 orang atau $18,2 \%$ menjawab netral, 6 orang atau 9,1\% menjawab tidak setuju dan tidak ada satupun responden yang menjawab sangat tidak setuju. Dari nilai rata-rata skor terlihat bahwa nilai 3.92 terletak pada kriteria sedang (rata-rata antara 3,41 hingga 4,20). Dengan demikian dapat disimpulkan bahwa indikator keenam dinilai tinggi oleh responden. 
Faktor-faktor Broaden Bulid yang Mempengaruhi Kinerja.... (Erna Retna Rahadjeng)

Dari nilai rata-rata keseluruhan Variabel Kinerja Lembaga Sekuritas terlihat bahwa nilai 3,88 terletak pada kriteria tinggi (rata-rata antara 3.41 hingga 4,20). Dengan demikian dapat disimpulkan responden menilai tinggi mengenai variabel kinerja Lembaga Sekuritas.

Analisis regresi berganda dengan korelasiberganda ini digunakan untuk mengetahui hubungan antara dua atau lebih variabel independen $\left(\mathrm{X}_{1}, \mathrm{X}_{2}, \ldots \mathrm{X}_{\mathrm{n}}\right)$ terhadap variabel dependen (Y) secara serentak. Koefisien ini menunjukkan seberapa besar hubungan yang terjadi antara variabel independen $\left(X_{1}\right.$, $\mathrm{X}_{2}, \ldots \ldots \mathrm{X}_{\mathrm{n}}$ ) secara serentak terhadap variabel dependen $(\mathrm{Y})$. Nilai $\mathrm{R}$ berkisar antara 0 sampai 1, nilai semakin mendekati 1 berarti hubungan yang terjadi semakin kuat, sebaliknya nilai semakin mendekati 0 maka hubungan yang terjadi semakin lemah.

Menurut Sugiyono (2007) pedoman untuk memberikan interpretasi koefisien korelasi sebagai berikut:

$$
\begin{aligned}
& 0,00-0,199=\text { sangat rendah } \\
& 0,20-0,399=\text { rendah } \\
& 0,40-0,599=\text { sedang } \\
& 0,60-0,799=\text { kuat } \\
& 0,80-1,000=\text { sangat kuat }
\end{aligned}
$$

Dari hasil analisis regresi, lihat pada output moddel summary dan disajikan pada tabel 5.

Berdasarkan tabel 5 diperoleh angka $\mathrm{R}$ sebesar 0,829. Hal ini menunjukkan bahwa terjadi hubungan yang sangat kuat antara variabel Emotional Resiliency, Cognitive Resiliency, Social Resiliency, dan Financial Resiliency dengan kinerja Lembaga Sekuritas di Malang.

Berdasarkan tabel 5 diperoleh angka Adjusted R Square sebesar 0,672 atau 67,2\%. Hal ini menunjukkan bahwa prosentase sumbangan pengaruh variabel independen (Emotional Resiliency, Cognitive Resiliency, Social Resiliency, dan Financial Resiliency) terhadap variabel dependen (kinerja Keuangan) sebesar $67,2 \%$. Atau variasi variabel independen yang digunakan dalam model (Emotional Resiliency, Cognitive Resiliency, Social Resiliency, dan Financial Resiliency) mampu menjelaskan sebesar 67,2\% variasi variabel dependen (Kinerja keuangan). Sedangkan sisanya sebesar 32,8\% dipengaruhi atau dijelaskan oleh variabel lain yang tidak dimasukkan dalam model penelitian ini.

Uji ini digunakan untuk mengetahui apakah variabel independen $\left(\mathrm{X}_{1}, \mathrm{X}_{2} \ldots \mathrm{X}_{\mathrm{n}}\right)$ secara bersama-sama berpengaruh secara signifikan terhadap variabel dependen(Y). Atau untuk mengetahui apakah model regresi dapat digunakan untuk memprediksi variabel dependen atau tidak. Signifikan berarti hubungan yang terjadi dapat berlaku untuk populasi (dapat digeneralisasikan). Dari hasil output analisis regresi dapat diketahui nilai F seperti pada tabel 6.

Tabel 5. Hasil Analisis Korelasi berganda

\begin{tabular}{ccccc}
\multicolumn{4}{c}{ Model Summary } \\
\hline \multirow{2}{*}{ Model } & $\mathrm{R}$ & R Square & $\begin{array}{l}\text { Adjusted } \\
\text { R Square }\end{array}$ & $\begin{array}{l}\text { Std. Error of } \\
\text { The Estimate }\end{array}$ \\
\hline 1 &, $829^{\mathrm{a}}$ &, 687 &, 672 & 2,67139
\end{tabular}

a. Predictors: (Constant), Aktivitas Investasi, Aktivitas Pembiayaan, Aktivitas Operasi

b. Dependent Variable: Kinerja Keuangan UKM

Sumber: Data Primer diolah, 2014 
Berdasarkan tabel 6 dapat diketahui nilai $F$ hitung sebesar 45,338. Menentukan F tabel dengan menggunakan tingkat keyakinan $95 \%, a=5 \%$, df 1 (jumlah variabel-1) $=$ 2, dan df 2 (n-k-1) atau 66-2-1 = 63 (n adalah jumlah kasus dan $\mathrm{k}$ adalah jumlah variabel independen), hasil diperoleh untuk F tabel sebesar 2,753. Karena F hitung $>$ F tabel (45,338 > 2.753), maka Ho ditolak, artinya ada pengaruh secara signifikan antara variabel Emotional Resiliency, Cognitive Resiliency, Social Resiliency, dan Financial Resiliency secara bersama-sama terhadap terhadap Kinerja Lembaga Sekuritas Di Malang. Jadi dari kasus ini dapat disimpulkan bahwa variabel Emotional Resiliency, Cognitive Resiliency, Social Resiliency, dan Financial Resiliency secara bersama-sama terhadap terhadap Kinerja Lembaga Sekuritas Di Malang. Selain membandingkan nilai $F$ hitung dan $F$ tabel, dengan membandingkan nilai Signifikan dengan nilai $\alpha$ yaitu Sig $<\alpha 5 \%(0.000<0.05)$ maka Ho ditolak dan Ha diterima, artinya variabel Emotional Resiliency, Cognitive Resiliency, Social Resiliency, dan Financial Resiliency secara bersama-sama (simultan) mempunyai pengaruh yang signifikan terhadap kinerja Lembaga Sekuritas di Malang.

Uji ini digunakan untuk mengetahui apakah dalam model regresi variabel independen $\left(\mathrm{X}_{1}, \mathrm{X}_{2}, \ldots . \mathrm{X}_{\mathrm{n}}\right)$ secara parsial berpengaruh signifikan terhadap variabel dependen (Y). Dari hasil analisis regresi output dapat disajikan pada tabel 4.16 sebagai berikut:

Berdasarkan Tabel 7, maka dapat dibuat model regresi linier berganda dengan persamaan sebagai berikut:

$\mathrm{Y}=-5,771+0.606 \mathrm{X} 1+0.648 \mathrm{X} 2+$ $0.445 \times 3+0.610+\mathrm{e}$

Nilai masing-masing koefisien regresi Variabel Independen dari model regresi linier tersebut memberikan gambaran bahwa: pertama, konstanta sebesar -5.771 artinya kinerja Lembaga Sekuritas akan menurun sebesar 5.771 dengan asumsi tidak ada variabel emotional resiliency, cognitive resiliensy, social resiliency, dan financial resiliency. Pertama, Koefisien Regresi Variabel Emotional Resiliency (X1) sebesar 0.606 menggambarkan bahwa Emotional Resiliency mempunyai pengaruh positif dan signifikan terhadap kinerja Lembaga Sekuritas di Malang, artinya dengan semakin besarnya Emotional Resiliency maka Kinerja Lembaga Sekuritas akan semakin meningkat.

Kedua, Koefisien Regresi Variabel Cognitive Resiliency (X2) sebesar 0.648 menggambarkan bahwa Cognitive Resiliency mempunyai pengaruh positif dan signifikan terhadap kinerja Lembaga Sekuritas di Malang, artinya dengan semakin tingginya Cognitive Resiliency maka kinerja

Tabel 6. Hasil Uji F

\begin{tabular}{|c|c|c|c|c|c|c|}
\hline \multicolumn{7}{|c|}{ ANOVA $^{\mathrm{b}}$} \\
\hline & Model & $\begin{array}{c}\text { Sum of } \\
\text { Squares }\end{array}$ & df & $\begin{array}{l}\text { Mean } \\
\text { Square }\end{array}$ & $\mathrm{F}$ & Sig. \\
\hline \multirow[t]{3}{*}{1} & Regression & 970,640 & 3 & 323,547 & 45,338 &, $000^{\mathrm{a}}$ \\
\hline & Residual & 442,451 & 62 & 7,136 & & \\
\hline & Total & 1413,091 & 65 & & & \\
\hline
\end{tabular}

a. Predictors: (Constant), Aktivitas Investasi, Aktivitas Pembiayaan, Aktivitas Operasi

b. Dependent Variable: Kinerja Keuangan UKM 
Faktor-faktor Broaden Bulid yang Mempengaruhi Kinerja.... (Erna Retna Rahadjeng)

Lembaga Sekuritas di Malang semakin meningkat.

Ketiga, Koefisien Regresi Variabel Social Resiliency (X3) sebesar 0.445 menggambarkan bahwa Social Resiliency mempunyaipengaruh positifterhadap kinerja Lembaga Sekuritas di Malang, artinya dengan semakin besarnya Social Resiliency, maka kinerja Lembaga Sekuritas di Malang semakin meningkat.

Keempat, Koefisien Regresi Variabel Financial Resiliency (X4) sebesar 0.610 menggambarkan bahwa Financial Resiliency mempunyai pengaruh positif terhadap kinerja Lembaga Sekuritas di Malang, artinya dengan semakin besarnya Financial Resiliency, maka kinerja Lembaga Sekuritas di Malang semakin meningkat.

Uji hipotesis secara parsial digunakan untuk mengetahui pengaruh dari masingmasing Variabel Independen terhadap Variabel Dependen. Uji ini dilakukan dengan membandingkan nilai $T$ hitung dengan nilai T tabel. Nilai T hitung dari hasil pengolahan data dengan program SPSS dapat dilihat pada Tabel 4.16 bagian Coefficients. Hipotesis Statistik yang diajukan untuk Uji T adalah untuk memperoleh nilai T tabel, dapat dilihat pada tabelT, yaitu pada Degrees of Freedom (df) sebesar 50 (jumlah data dikurangi jumlah variabel) dan $1 / 2 \alpha=10 \% / 2=5 \%$ (uji dua arah) maka nilai T tabel sebesar 1,997.
Dengan membandingkan nilai $\mathrm{T}$ hitung dengan T tabel maka dapat disimpulkan: pertama, variabel Emotional Resiliency, yaitu T hitung > T tabel atau 3,668 > 1,997 maka Ho ditolak dan hipotesis penelitian diterima, artinya Emotional Resiliency mempunyai pengaruhyang signifikan terhadapkinerja Lembaga Sekuritas di Malang.

Kedua, variabel Cognitive Resiliency, yaitu T hitung > T tabel atau 4,497 > 1,997 maka Ho ditolak dan hipotesis penelitian diterima, artinya Cognitive Resiliency mempunyai pengaruh yang signifikan terhadap Kinerja Lembaga Sekuritas di Malang.

Ketiga, variabel Social Resiliency, T hitung > T tabel atau 3,438 > 1,997 maka Ho ditolak dan hipotesis penelitian diterima, artinya Social Resiliency mempunyai pengaruh yang signifikan terhadap kinerja Lembaga Sekuritas di Malang.

Keempat, variabel Financial Resilien$c y$, yaitu T hitung $>\mathrm{T}$ tabel atau 3,553 > 1,997 maka Ho ditolak dan hipotesis penelitian diterima, artinya Financial Resiliency mempunyai pengaruh yang signifikan terhadap kinerja Lembaga Sekuritas di Malang.

Pada uraian di atas telah dilakukan analisis data dan pengujian terhadap 4 hipotesis. Berdasarkan hasil kuesioner dapat diketahui bahwa para pelaku pasar modal yang ada di Malang memiliki pendidikan tinggi rata-rata

Tabel 7. Hasil Uji T

\begin{tabular}{llllll}
\hline \multicolumn{1}{c}{ Model } & \multicolumn{2}{c}{$\begin{array}{c}\text { Unstandardzec } \\
\text { Coefficients }\end{array}$} & $\begin{array}{l}\text { Standardzed } \\
\text { Coefficients }\end{array}$ & $\mathrm{t}$ & $\mathrm{sig}$ \\
\hline Constant & -5.771 & 2.630 & & -2.194 & .032 \\
Emotional Resiliency & .606 & .165 & .353 & 3.668 & .001 \\
Cognitive Resiliency & .648 & .144 & .365 & 4.497 & .000 \\
Social Resiliency & .445 & .130 & .309 & 3.438 &, 001 \\
Financial Resiliency & .610 & .150 & .355 & 3.553 & .001 \\
\hline
\end{tabular}

a. Dependent variabel Kinerja Lembaga sekuritas

Sumber: Data Primer diolah (2014) 
Sarjana. Hal ini menunjukkan bahwa pendidikan masih sangat dibutuhkan dalam masyarakat Malang dalam berinvestasi di pasar modal, karena dalam membaca informasi dibutuhkan pendidikan formalmaupun non formal. Begitu pula para pengusaha yang ada rata-rata memilikiusia di atas 30 tahun artinya bahwa yang menjadi pelaku para modal sebaiknya investoryang memiliki usia diatas 30 karena dalam pengambilan keputusan berinvestasiharus memilikiwawasan yang luas dan bisa membaca informasi pasar dengan baik. Untuk meningkatkan kinerja diperlukan pendidikan yang lebih tinggi dan pelaku pasar modal yang memilikiusia dewasa untuk bisa menjadi pelaku pasar modal.

Berdasarkan hasil analisis, untuk mengetahui variabel-variabel yang mempengaruhi kinerja Lembaga Sekuritas digunakan analisis regresi berganda agar dapat diketahui pengaruh secara bersama-sama dan secara parsial. Hasil yang diperoleh menunjukkan bahwa semua hipotesis dapat diterima karena variabel (x1) Emotional Resiliency; (x2) Cognitive Resiliency;(x3) social resiliency; dan Financial Resiliency (x4) secara bersama memiki pengaruh terhadap kinerja Lembaga Sekuritas, Begitu juga secara parsial variabel Cognitive Resiliency memiliki pengaruh dominan terhadap kinerja Lembaga Sekuritas karena memiliki nilai koefisien regresi lebih besar dibanding dua variabel yang lain.Hasil penelitian inijuga didukung daripeneliti terdahulu yang menyatakan bahwa variabel (x1) Emotional Resiliency; (x2) Cognitive Resiliency;(x3) social resiliency; dan Financial Resiliency (x4) mempunyai pengaruh terhadap kinerja Lembaga Sekuritas.

Hasil penelitian ini juga didukung dengan teori dari Pearce and Robinson (2009) yang menyatakan kinerja dari sebuah usaha ditentukan oleh strategi bisnis yang diterapkan. Strategi yang menghasilkan kinerja ting- gi diidentifikasikan dengan aktivitas yang secara umum membuahkan keberhasilan dalamindustri. Begitu pula pendapat Miller and Freisen (1984), menyatakan bahwa aktivitas-aktivitas tersebut dikaitkan dengan inisiatif-inisiatif atau inovasi dalam industri sehingga akan menghasilkan kinerja yang baik bagi industri.

\section{Penutup}

Berdasarkan Hasil analisis pada bab sebelumnya, maka dapat ditarik kesimpulan bahwa Variabel (x1) Emotional Resiliency; (x2) Cognitive Resiliency;(x3) social resiliency; dan Financial Resiliency(x4) secara bersama-sama mempunyai pengaruh yang signifikan terhadap kinerja Lembaga sekuritas. Begitu pula secara parsial masing-masing variabel memiliki pengaruh terhadap kinerja keuangan. Variabel yang dominan berpengaruh terhadap kinerja lembaga Sekuritas adalah variabel cognitive resiliency yang memiliki nilaikoefisien regresi tertinggi. Sehinggahipotesis yang menyatakan adanya pengaruh variabelEmotional Resiliency; Cognitive Resiliency; social resiliency; dan Financial Resiliency terhadap kinerja Lembaga Sekuritas di Malang diterima.

Berdasarkan hasil penelitian, Lembaga Sekuritas di Malang belum sepenuhnya mampu mengelola Pelaku pasar modal dengan baik sehingga di sarankan untuk pelaku pasar modal agar menggunakan informasi yang ada baik darimedia maupun yang dicetak oleh lembaga sekuritas agar memperhatikan variabel Emotional Resiliency; Cognitive Resiliency; social resiliency; dan Financial Resiliency bisa terarah. Selain itu juga peran pemerintah sangat mendukung untuk lembaga sekuritas yang ada di Malang.

Berdasarkan hasil analisis data diharapkan para pelaku pasar modal sebaiknya mempertimbangkan dalam mengambil keputusan 
Faktor-faktor Broaden Bulid yang Mempengaruhi Kinerja.... (Erna Retna Rahadjeng)

dalam mengelola lembaga sekuritasnya sebaiknya mempertimbangkan variabel Emotional Resiliency; (x2) Cognitive Resiliency; (x3) social resiliency; dan Financial Resiliency agar dapat memberikan Keuntungan dari investasinya yang semakin meningkat.

Bagi pemerintah sebaiknya mempertimbangkan untuk selalu memberikan pembinaan dan mengayomi Lembaga sekuritas yang ada di daerahnya khususnya Kota Malang agar dapat mengangkat nama baik bagi daerah yang memiliki potensi besar dalam mengentas para investor daerah.

Berdasarkan hasil penelitian sebaiknya para peneliti selanjutnya dapat melakukan penelitian yang lebih baik lagi terlebih pada jumlah lembaga Sekuritas yang ada di Malang lebih diperluas tidak hanya pada satu kota saja, tetapi semakin banyak lembaga sekuritas yang ditelitiakan memberikan hasil yang lebih baik.

\section{DAFTAR PUSTAKA}

Cohn, MA; BLFredrickson. 2006. Beyond the Moment, Beyond the Self: Shard Ground between Selective Investment Theory and the Broaden-and-Build Theory of Positive Emotions". Psychological Inquiry.

Compton, William C. 2005. An Introduction to Positive Psychology. Wadsworth Publishing. pp. 23-40. ISBN 0-53464453-8.

Fredrickson, BL 2001. The Role of Positive Emotions in Positive Psychology. American Psychologist 56 (3): 218$226 . \quad$ doi: $10.1037 / 0003-$ 066X.56.3.218. PMID 11315248.

Fredrickson, B.L. 2003. The Value of Positive Emotions. American Scientist, 91, 330-335.
Gibson, J.L., J.M. Ivancevich, J.H. Donnelly, Jr. 1996. Organisasi, Perilaku, Struktur, Proses. Bina Rupa Aksara, hlm 119-275. Jakarta.

Robbins, Stephen, dan Timothy A., Judge. 2008. Perilaku Organisasi, Organizational Behaviour. Gramedia. Jakarta.

Wibowo. 2010. Manajemen Kinerja. PT. Raja Grafindo Persada. Jakarta. 
